\title{
Disruption Innovation and Theory
}

\author{
Oroszi Terry \\ Department of Pharmacology \& Toxicology, Wright State University, Dayton, Ohio, USA \\ Email: terry.oroszi@wright.edu
}

How to cite this paper: Terry, O. (2020). Disruption Innovation and Theory. Journal of Service Science and Management, 13, 449-458.

https://doi.org/10.4236/jssm.2020.133030

Received: March 26, 2020

Accepted: May 15, 2020

Published: May 18, 2020

Copyright (c) 2020 by author(s) and Scientific Research Publishing Inc. This work is licensed under the Creative Commons Attribution International License (CC BY 4.0).

http://creativecommons.org/licenses/by/4.0/

\begin{abstract}
Disruptive technology was a term coined by Harvard business professor Clayton Christensen in his book Innovators Dilemma. Disruptive technology opens up windows of opportunity for new products. It can enable low-income markets to have a piece of otherwise inaccessible technology. Education and health care are not immune to disruptive technology. Distance learning has a new and significant role in the education market, displacing traditional education. The healthcare industry is currently in trouble and hospitals are losing millions. The industry has identified several disruptive innovations that have decreased this loss. Disruptive technologies join the marketplace by offering more cost-efficient products and cater to a different consumer base. This paper will describe in detail Disruptive Technology and how it applies to business, education, and healthcare as a low-level entrant into the marketplace. It will also discuss how organizations can successfully meet the challenge of disruptive technology. Recent studies independently inferred that the theory is unsupported and attacked the authenticity of Christianson's claims. In The Innovator's Dilemma and its follow-up, The Innovator's Solution, Christensen cites 77 disruptive cases. However, here the researchers posit only 9 percent of the cases fit this theory. The attacks have not dimmed disruption's popularity as a theory or as a buzzword.
\end{abstract}

\section{Keywords}

Breakthroughs, Christensen, Disruptive Technology, Education, Emerging

Technology, Healthcare, Innovation, Innovation Technology, Online

Education, Pandemic, Telehealth

\section{Introduction}

Disruptive technology calls for a change in the way we look at market failures and the impact of new technologies. Productive, successful companies can make a critical error by neglecting to keep up in a rapidly changing marketplace. Corporate leadership must appreciate the potential impact and competition of a low 
cost or in some way lesser product. This paper seeks to explain how disruption technology works, and why.

Examples of disruption technology can be seen in several areas such as:

- Big business, when current high-profit margin producing products fail. Organizations fail to succeed because their managers are blind to the insurgence of new technology. A new technology that starts as a lesser product that does not represent competition can evolve and compete with established high-quality products. The new product starts slowly, typically marketing to a different consumer base. It then improves as it expands its resources and gains ground among consumers until it saturates the market. During this expansion, the technology is refined in response to feedback from consumers and becomes established. The exposure, rapid improvements and market momentum allow infiltration into a broader consumer range. The new technology gains a strong foothold in the market, displacing existing popular brands.

- Universities offering online learning have gained in popularity and give the university experience to those that may otherwise miss out. When online universities came into existence, they were seen as an inferior product, and leaders in higher education at brick and mortar schools believed they did not represent serious competition for students and would not last. Not only are they still around, but they are also growing in popularity. According to the U.S. Department of Education, National Center for Education Statistics (2013), in 2011, the postsecondary institution with the highest enrollment in the United States was the University of Phoenix, an online-only, for-profit university.

- Health care costs more and more; however, hospitals serving the general public are failing to show a profit. The question we ask is do we want disruptive technology involved in our health care? The idea that healthcare needs can be met with a low cost, inferior product sounds counterintuitive. The fact is that lower cost does not necessarily equal inferior. The skills necessary to meet the treatment needs of patients vary greatly. The alternatives to the traditional Medical Doctor include Nurse Practitioner and Physician Assistant, both very capable of assessing, diagnosing and treating many general healthcare needs. This allows for the concentration of expertise by highly trained and specialized physicians to see patients that need more specialized care.

\section{Purpose Statement}

Disruptive technology was a term coined by Harvard business professor Clayton Christensen in his book Innovators Dilemma (1997). This paper will describe in detail Disruptive technology and how it applies to business, education, and healthcare as a low-level entrant into the marketplace. It will also discuss how organizations can successfully meet the challenge of disruptive technology.

\section{Big Idea}

Disruptive technologies are low-level technologies that appear on the market 
under the radar, and overtime are continually upgraded, or they create entirely new technology (Kostoff, Boylan, \& Simons, 2004). A low-level disruptive product, when newly on the market, meets one of the following criteria: smaller, cheaper, lighter, more convenient, while being simultaneously lesser, either in quality, or power (Christensen, 2013; Kostoff et al., 2004).

Although the product is initially ignored by mainstream consumers, it improves and eventually appeals to them, (Schmidt \& Druehl, 2008). The appeal of the lesser product may be that it is cheaper, like some of the original clothing stores, or mobility and sound, size and memory, or processing speed. These products appeal to those who may not be able to afford an established, high cost, high-quality product. The irony is that the new disruptive innovation has a non-disruptive entrance into the market because of its inferior quality and customer base. The new product is viewed as non-threatening (Schmidt \& Druehl, 2008).

Products that are identified as low level disruptive, starting as an inferior product and improving substantially include:

- The personal computer (PC) did not have the processing power to compete with the minicomputers the PC was considered more of a children's toy than the competition (Christensen \& Overdorf, 2000).

- Toyota, a disruptive entity that first joined the American market with a low-end low-profit car, not threatening GM or other US car companies. Eventually, Toyota developed the Camry and Lexus and threatened the others (Schmidt \& Druehl, 2008).

- Charles Schwab, a bare-bones discount broker, now competing with full-service brokers Merrill Lynch (Christensen \& Overdorf, 2000).

- Steel mills failed to be intimidated by the inferior product rebar, produced by mini-mill makers and this lack of concern was a detriment (Christenson, 1997).

- Quicken creator Intuit recognized a need for a product that could meet the needs of the home user and created QuickBooks, an inferior product without the extras (Christensen, Aaron, \& Clark, 2003).

- Wal-Mart disrupted traditional downtown department stores and became part of a new discount retailer market (Christensen et al., 2003). Dayton Hudson met the challenge and created Target, slowing decreasing the original output and investing it all into discount retail (Christensen \& Overdorf, 2000).

- Online MBA programs geared at the international community are available to anyone with access to the internet with an expected total cost of $\$ 5000.00$.

- Learning technologies used in the massive open online courses (MOOC) will change the way people think about online education (DiSalvio, 2012; Al-Imarah \& Shields, 2019) and make an Ivy League education available to anyone.

- Armada \& Martin (2016) mentioned programs at MedStar Health and OSF Healthcare driving innovation in Healthcare. 
- Alternatives to hotels, motels, and hostels. Airbnb offers homeowners the ability to rent out space to travelers needing a place to stay and by doing so they have disrupted the tourism industry (Guttentag \& Daniel, 2015).

In direct contrast to low-level disruption, we have new market disruptions, similar to sustaining innovation; it directly competes with the existing technology and typically includes high end, high-cost products joining the marketplace at a level of direct competition with in-demand products. An example of this is the Apple iPod, in late 2001 and the cell phone, competing with landlines (Schmidt \& Druehl, 2008).

\section{Connections/Synthesis}

Few established companies innovate successfully. Businesses and major corporations are not the only ones to see disruptive innovations on their doorstep; education and healthcare have also been privy to such trepidation. Disruptive technology has changed the face of education and can change health care practices in the United States.

Never before have we as a nation been more prepared to take our education online. The ability of students to embrace the technology and see the benefits of studying long-distance, versus in a classroom, does not have to come at a cost to the education of the student, but this has not always been so (Glenn \& D'Agostino, 2008). Distance learning and corporate universities are growing exponentially, exceeding the traditional "brick and mortar" education. According to Christensen, Aaron, and Clark (2003), corporate training is a $\$ 32$ billion annual industry and in the past decade, 500 traditional academic institutions have closed. Online education fits the disruptive technology model introduced by Christensen (1997). When it was first introduced online courses were seen as an inferior alternative to standard lectures in traditional classrooms. The leaders of those universities, including administration, finance, and faculty within those facilities were not intimidated by the onslaught of online for-profit universities like Phoenix. The commonly held belief was that employers would not accept the online degrees, and would give preference to graduates with traditional degrees. They believed that the online phase would pass, that this inferior product could not compete. As technology improved for online teaching, the online courses became more comprehensive, better organized and became a popular alternative to traditional coursework (see Figure 1) (Christensen et al., 2003).

To counter this online craze, the traditional school can offer more online courses and programs, reaching out to a greater population and taking advantage of current technology (see Figure 2). Like corporations, this change can be met with resistance by faculty that are intimidated by online education or still believe that the classroom is better. Once again the culture competes with new technology, creating a barrier that may eventually cause the universities' downfall with a decrease in student enrollment and revenue (Christensen et al., 2003).

Affordable, accessible education is an example of the benefit of destructive 


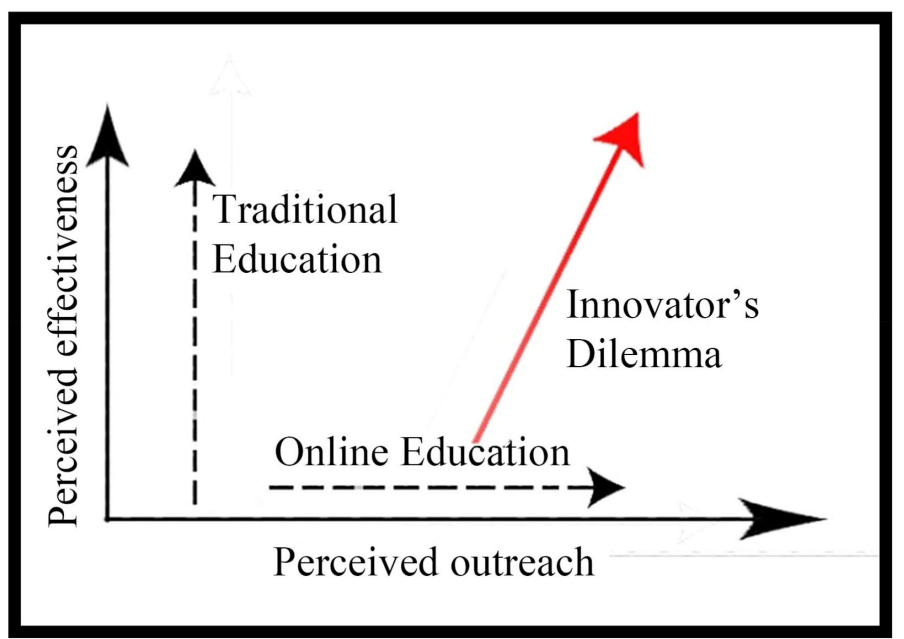

Figure 1. As online education grows, as a product improves and takes over the market.

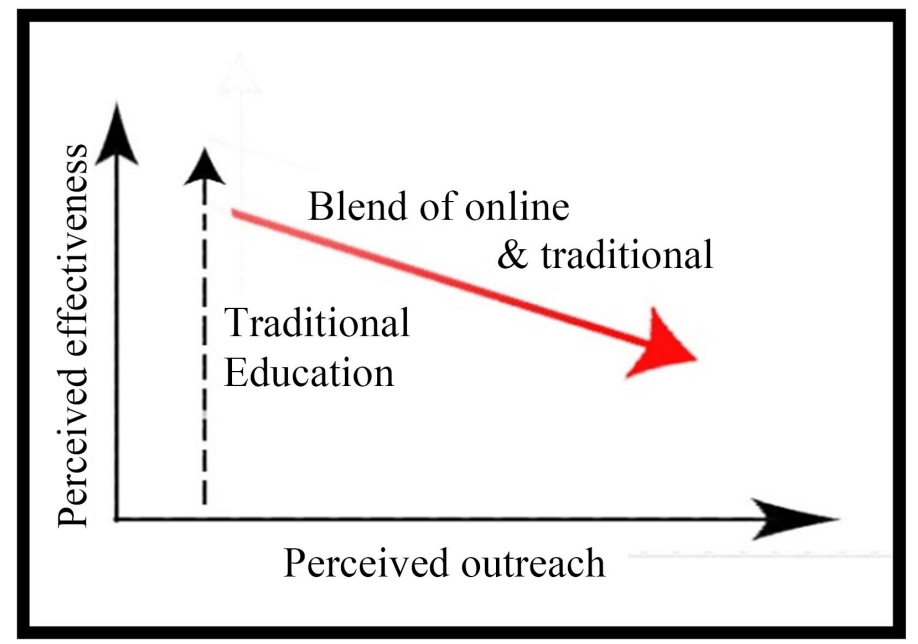

Figure 2. To compete with online universities, traditional schools need to create online courses or programs that can curb the disruptive advantage.

innovation. Another example can be seen in the healthcare industry. Is affordable healthcare a solution for the poor? Would a less costly alternative be helpful, or a detriment? A low-cost instrument that does not provide effective diagnosis and treatment would not be helpful; however, a few big picture issues can be addressed.

The healthcare industry is in trouble. Hospitals are losing millions. Healthcare is expensive and patients are not happy with their care. Physicians are highly educated, highly skilled individuals, but to make money they see and treat patients suffering from the common cold, or similar problems that can be diagnosed by a less skilled nurse practitioner, the less skilled practitioner is the disruptive technology in this example. Another example of disruptive technology in the world of healthcare is the technology used for in-home management of chronic illness. What used to require constant monitoring by physicians can now, due to technology, be treated at home, with routine supervision by a nurse. 
An example of this is the disease, diabetes. There is no longer a need for more blood work or urine tests, now a personal meter allows patients to self-manage. The glucose meter is an example of destructive technology (Christensen, Bohmer, \& Kenagy, 2000).

Specialization in treatment can also be seen as disruptive. Clinics treating select diseases are showing a profit, and pharmacies and clinics providing vaccines, school, and sports physicals and prescription consults. These services are convenient, usually close to home, cost-effective for the patient and do not include billing for unnecessary room use, tests, appointment fees, etc. usually associated with a visit to the doctor's office or the hospital. These innovations also free up physicians to focus on their area of specialty, putting their education to good use and improving their skills in the area by focusing on patients specific to the disease or area of interest. General hospitals' offer more care than the needs of most of their patients, and contributes to the loss of revenue (Christensen et al., 2000).

\section{Impact, Significance or Proposed Investigation}

Medical and business schools are failing to change their curriculum fast enough to keep up with the kind of training doctors and business managers needed today. The resources are there, but managers cannot identify the new needs and the ability to assess their companies' ability to accomplish new tasks. Making drastic changes to an existing organization may lead to failure due to the inability or the organization to sustain the change (Christensen \& Overdorf, 2000).

Companies pursuing a disruptive approach to serving their customer market should expect it to be costly (Christensen et al., 2003). Incumbent organizations fail to identify disruptive products, the threat they pose and then are overthrown (Christensen, 2013; Schmidt \& Druehl, 2008). Why organizations fail to conquer disruptive technology is a topic of much debate and an understanding of an organization and its leaders may shed light on why this happens.

Before determining if a new market entity will be able to compete or become a disruptive technology, more must be known. We need to assess the organization's ability to change. Factors that influence its operations are resources, processes, and values. Tangible resources, resources, like people, cash, equipment, or intangible resources, like designs, brands, and relationships, define what an organization can do. Processes are characterized as the methods the employees use to transform the resources into a product. These processes may be defined and documented formally, others may be informal (way of working, evolving over time), and contribute to the organization's ability to make decisions, or budgets, changes of processes are not welcomed. Values are the standards a company uses to assign worth or prioritize the needs or decisions of the company. The larger the company the more difficult it is to dissociate itself from the current operation and introduce a new product. The values may be the biggest hurdle to accept new ideas and facilitate the success of disruptive innovation (Christensen \& Overdorf, 2000; Christenson, 1997). 
A company with overhead costs, shareholders, and resources available specifically designed to make a profit may not be amendable to welcoming a new product that would be required to compete or defeat the disruptive product. A new product would require different resources or diverting resources from an existing product, and is unlikely to produce a marginal profit initially. When the company is trying to maintain growth with its current products, marketing and selling of those products will have priority, as will the resources necessary to maintain the tried and true. Opting to start a new product line within an existing company becomes an unattractive option. Especially when the product is inferior and attacks the values or culture of a company that offers only cutting edge, top of the line (Christensen \& Overdorf, 2000).

The new disruptive technology, when introduced by a startup company, or a spin-off company, can appreciate smaller profit margins, they can embrace small wins, and their values can support small markets. They are not encumbered with large cost structures, or barriers to change that existing companies' experience. Within a new company, fewer people can have a larger impact on decisions that influence success or change within the organization. A mature company's processes, values, and priorities become part of the culture and resistance to new ideas is common. That which has helped make a well-established business may contribute to its death (Christensen \& Overdorf, 2000).

\section{Disruption 2020}

Several factors drive disruption, including cost, quality, customers, regulations and available resources (Miller, 2018). The most disruptive technologies in 2020 will include automation, the internet of things (IoT), digital twinning, digital currency interactions, and enhanced smart technology. Home owners are leaning toward smaller living, choosing tiny home construction, van living, and recycling storage containers. Boomer retirees are part of the movement, but the millennials are leading the disruption. When compared to previous generations, they are traveling less and more likely to use alternative modes Garikapati, Pendyala, Morris, Mokhtarian, \& McDonald (2016). With technologies such as telehealth, home healthcare equipment, e-records any health care organization not thinking ahead will fall behind.

Innovation disruption was supposed to prevent the next pandemic. In 2015, Shaikh, Ferland, Hood-Cree, Shaffer, \& McNabb said transforming public health surveillance methods to meet the needs of the twenty-first century requires novel approaches. They believed disruptive technology could overcome these challenges. Improvements include digital tools to create electronic-based surveillance. The standardization of vocabularies to allow cross communications, and online training programs, such as the MOOCs mentioned above, opened universal educational opportunities. During the SARS epidemic, learning through simulation minimized disruptions to medical education. Technologies, such as the use of web-based learning, medical gaming, video vignettes, and manne- 
quin-based simulated patients improved the training of medical students and residents and allows medical education to continue without a need for human contact (Lim, Oh, Koh, \& Seet, 2009). While disruption innovation did not prevent the next pandemic, COVID19, the technology espoused here were implemented to maintain the social distancing, to keep academic institutions open, to triage over the internet, and to communicate statistics globally (Smith, Thomas, Snoswell, Haydon, Mehrotra, Clemensen, \& Caffery, 2020).

\section{Summary}

Disruptive technology opens up windows of opportunity for new products. It can enable low-income markets to have a piece of otherwise inaccessible technology. The new inferior product offers something different, and reaches out to a typically lower-income market, i.e. a smaller portable product that is more convenient (Christensen, 2013; Kostoff et al., 2004). In time the disruptive product improves and becomes more competitive. Low-level disruption is not the only disruption mentioned in Christensen's book. New market disruptions directly compete against high end, high-cost products (Schmidt \& Druehl, 2008).

Education and healthcare are not immune to disruption technology. Distance learning has a new and large part of the education market, displacing traditional education. As technology improved for online teaching the online courses became less inferior and started competing with the traditional schools (Christensen et al., 2003). Affordable, accessible education and healthcare are important at a local, national, and global level. Highly trained physicians are over skilled to treat the majority of their patients. Finding other technology to allow less direct physician monitoring, more self or practitioner supervision improves healthcare.

Disruptive technologies join the marketplace by offering more cost-effective products and cater to a different consumer base. As the inferior product takes hold in the market it improves with technology and ultimately becomes an acceptable product to the original market as well. It gains reputation and gradually is viewed as a viable alternative or even a superior alternative to the products from established companies (Christenson, 1997; Henderson, 2006) believes that managers cannot grasp the power of disruptive innovation because their views are shaped by experience and current customer base. By focusing on current customers, they are blind to potential market opportunities or start-up threats.

According to Christensen (2000), large companies can compete with the disruptive low-end product competing in a new space (spinoff Company) for the competitive product. The ability to break away from the resources, values, and processes of the parent company will offer a chance of success. Another way large organizations can compete is to purchase an existing company that has values and processes closely aligned with the needs of the new product.

In 1984 IMB acquired Rolm because of Rolm's processes for new market development; however, when the subsidiary status was revoked and Rolm was absorbed into IBM the integration was proved to be a detriment. The very things 
that made Rolm a value were lost when the values, resources, and processes merged (Christensen \& Overdorf, 2000). Successful companies that opt to invest in disruptive technology may not only steer resources away from their current invested products, they may also lose their place in their respective fields, or be removed altogether. It is not an easy risk to make for any organizational leader (Kostoff et al., 2004); the hope for high payoff does not always make the risk acceptable. The organizations that can disrupt themselves will be the ones to come out ahead (McQuivey, 2013).

Globalization has drastically changed our interactions with the biological world. A novel pathogen discovered in one part of the globe can be easily carried thousands of miles away in a single day. Our crisis leaders are taking full advantage of the latest technologies and processes to obtain information required to make informed decisions. Disruptive innovations are not always the most advanced technologies. They are most often a combination of existing technologies or processes, offering simple, easily obtainable and affordable alternatives. Disruptions in current structures and processes will transform current practices and continue to not only improve lives but save them as well.

When we are met with challenges we step up and innovate. In 2020 our world changed with the COVID19 virus. Where this will take us will be exciting to witness. New technologies will be created, and as a species, we will adapt, and thrive. New meeting styles will likely be developed, safety nets in place to save small businesses, and our education system may become more online than in the classroom. As we adjust to working from home, we learn skills to cope and become more productive, thus requiring new organizational products.

\section{Conflicts of Interest}

The authors declare no conflicts of interest regarding the publication of this paper.

\section{References}

Al-Imarah, A. A., \& Shields, R. (2019). MOOCs, Disruptive Innovation and the Future of Higher Education: A Conceptual Analysis. Innovations in Education and Teaching International, 56, 258-269. https://doi.org/10.1080/14703297.2018.1443828

Armada, A. A., \& Martin, A. (2016). Business Model Disruption: Innovation as a Catalyst. Frontiers of Health Services Management, 33, 39-44.

https://doi.org/10.1097/01974520-201610000-00006

Christensen, C. (2013). The Innovator's Dilemma: When New Technologies Cause Great Firms to Fail. Brighton, MA: Harvard Business Review Press.

Christensen, C. M., Aaron, S., \& Clark, W. (2003). Disruption in Education. Educause Review, 38, 44-55.

Christensen, C. M., Bohmer, R., \& Kenagy, J. (2000). Will Disruptive Innovations Cure Health Care? Harvard Business Review, 78, 102-112.

Christensen, C. M., \& Overdorf, M. (2000). Meeting the Challenge of Disruptive Change. Harvard Business Review, 78, 66-77. 
Christensen, C. (1997). The Innovator's Dilemma. Cambridge, MA: Harvard Business School Press.

DiSalvio, P. (2012). Pardon the Disruption... Innovation Changes How We Think about Higher Education. New England Journal of Higher Education. https://nebhe.org/journal/disruptive-innovation-changing-how-we-think-about-higher -education/

Garikapati, V. M., Pendyala, R. M., Morris, E. A., Mokhtarian, P. L., \& McDonald, N. (2016). Activity Patterns, Time Use, and Travel of Millennials: A Generation in Transition. Transport Reviews, 36, 558-584. https://doi.org/10.1080/01441647.2016.1197337

Glenn, M., \& D’Agostino, D. (2008). The Future of Higher Education: How Technology Will Shape Learning. New Media Consortium, 1-27.

Guttentag, D. (2015). Airbnb: Disruptive Innovation and the Rise of an Informal Tourism Accommodation Sector. Current Issues in Tourism, 18, 1192-1217. https://doi.org/10.1080/13683500.2013.827159

Henderson, R. (2006). The Innovator's Dilemma as a Problem of Organizational Competence. Journal of Product Innovation Management, 23, 5-11. https://doi.org/10.1111/j.1540-5885.2005.00175.x

Kostoff, R. N., Boylan, R., \& Simons, G. R. (2004). Disruptive Technology Roadmaps. Technological Forecasting and Social Change, 71, 141-159. https://doi.org/10.1016/S0040-1625(03)00048-9

Lim, E. C., Oh, V. M., Koh, D. R., \& Seet, R. C. (2009). The Challenges of "Continuing Medical Education" in a Pandemic Era. Annals of the Academy of Medicine of Singapore, 38, 724-726.

Millar, C., Lockett, M., \& Ladd, T. (2018). Disruption: Technology, Innovation and Society. Technological Forecasting and Social Change, 129, 254-260. https://doi.org/10.1016/j.techfore.2017.10.020

McQuivey, J. (2013). Digital Disruption: Unleashing the Next Wave of Innovation.

Schmidt, G. M., \& Druehl, C. T. (2008). When Is a Disruptive Innovation Disruptive? Journal of Product Innovation Management, 25, 347-369. https://doi.org/10.1111/j.1540-5885.2008.00306.x

Shaikh, A. T., Ferland, L., Hood-Cree, R., Shaffer, L., \& McNabb, S. J. (2015). Disruptive Innovation Can Prevent the Next Pandemic. Frontiers in Public Health, 3, 215. https://doi.org/10.3389/fpubh.2015.00215

Smith, A. C., Thomas, E., Snoswell, C. L., Haydon, H., Mehrotra, A., Clemensen, J., \& Caffery, L. J. (2020). Telehealth for Global Emergencies: Implications for Coronavirus Disease 2019 (COVID-19). Journal of Telemedicine and Telecare. https://doi.org/10.1177/1357633X20916567 